\title{
Soil Erosion and Crop Productivity Loss for Raigad District of Konkan Region
}

\author{
Madhuri Phadtare $^{1}$, Sachin Nandgude ${ }^{2}$, Sanjani Salunkhe $^{{ }^{*}}$ and Dilip Mahale ${ }^{1}$ \\ ${ }^{1}$ Department of Soil and Water Conservation Engineering, Dr. BalasahebSawant Konkan \\ KrishiVidyapeeth, College of Agricultural Engineering and Technology, \\ Dapoli, 415712, India \\ ${ }^{2}$ Department of Soil and Water Conservation Engineering, Dr. A. Shinde College of \\ Agricultural Engineering and Technology Rahuri, Mahatma PhuleKrishiVidyapeeth, Rahuri, \\ 413722, India \\ *Corresponding author
}

\section{A B S T R A C T}

\begin{tabular}{|c|}
\hline Keywords \\
\hline $\begin{array}{l}\text { Soil erosion, } \\
\text { Tolerable soil loss, } \\
\text { RS and GIS, USLE, } \\
\text { Conservation } \\
\text { practice factor }\end{array}$ \\
\hline Article Info \\
\hline $\begin{array}{l}\text { Accepted: } \\
08 \text { January } 2020 \\
\text { Available Online: } \\
10 \text { February } 2020\end{array}$ \\
\hline
\end{tabular}

Soil erosion is the common land degradation problem in the worldwide, and also is one of the most critical environmental hazards of recent times, which reduces productivity. Assessment of soil erosion is expensive and intensively long exercise. In the present study an USLE model has been used for estimation of soil loss for Raigad district of Konkan region of Maharashtra. Conservation practice factors were recommended to reduce the soil loss below tolerable limit. The predicted average annual soil loss by USLE from Raigad district was found as $38.22 \mathrm{t}$ ha/yr before adoption of soil and water conservation measures. About $80 \%$ of area from Raigad district comes under severe (20-40 t ha/yr) to extremely severe (>80 t ha/yr) erosion classes. This indicates to adopt soil and water conservation measures on watershed basis for sustainable development of soil and water. It proves urgent need of adoption of conservation measures. Estimated conservation factor was 0.32 to bring the soil loss within tolerable limit. Thus, the soil loss after adoption of soil and water conservation measures for Raigad district was $9.18 \mathrm{t} \mathrm{ha}^{-1} \mathrm{yr}^{-1}$. Although, study indicates that the soil erosion and crop productivity loss can be effectively used for conservation measures in study area.

\section{Introduction}

Balanced ecosystems comprising soil, water and plant environments are essential for the survival and welfare of mankind. However, ecosystems have been disturbed in the past due to over exploitation in many parts of the world, including some parts of India. The resulting imbalance in the ecosystem is revealed through various undesirable effects, such as degradation of soil surfaces, frequent occurrence of intense floods etc. (Kothari, 1996).

One of the most serious land degradation problems is soil erosion. It is defined as the 
loosening, dissolving and removal of rock materials from all parts of the earth's surface by a complex interaction process of many factors such as natural like climate, topography, soil, vegetation and anthropogenic like tillage systems, soil conservation measures, overgrazing and deforestation (Belasri and Lakhouili, 2016).

Soil degradation by accelerated erosion is a serious problem and will remain so during the $21^{\text {st }}$ century and its severity and economic and environmental impacts are debatable (Lal, 2001). Soil erosion on cultivated lands has received much concern since it is considered to be one of the most critical forms of degradation (Montgomery, 2007).

In recent years, soil degradation has reached alarming proportions in many parts of the world, especially in the tropics and subtropics. In India, about $53 \%$ of the total land area is prone to erosion and has been estimated that about 5,334 $\mathrm{M}$ tons of soil is being detached annually due to various reasons (Narayana and Babu, 1983). Soil degradation in India is estimated to be occurring on 147 million hectares (Mha) of land, including 94 Mha from water erosion, 16 Mha from acidification, 14 Mha from flooding, 9 Mha from wind erosion, 6 Mha from salinity and 7 Mha from a combination of factors (Bhattacharyya et al., 2015). Maharashtra is also facing similar level of severity in soil erosion. The quantity of soil erosion per year in Maharashtra is $773.5 \mathrm{M}$ tons and $94 \%$ of that erosion is water induced (Durbude, 2015).Assessment of soil erosion is an expensive and intensively long exercise. A number of parametric models have been developed to forecast soil erosion at drainage basins. Universal Soil Loss Equation i. e. USLE (Wischmeier and Smith, 1978) is the most popular empirically based model used globally for erosion prediction and control.
This kind of study is very essential in Konkan region of Maharashtra due to extreme weather conditions and huge loss of soil through runoff. It is part of Western Ghats which comes under one of 34 world biodiversity hotspots (Myers et al., 2000). So, Raigad district is ecologically sensitive region of coastal area where natural resources need to be protected with maximum care.

The Remote Sensing (RS) and GIS tools have become valuable specially when assessing erosion at larger scales due to the amount of data needed and the greater area coverage (Parveen and Kumar, 2012). The combined use of GIS and erosion models, such as USLE/RUSLE, has been proved to be an effective approach for estimating the magnitude and spatial distribution of erosion. In the present study of soil loss and crop productivity loss of Raigad District was estimated using RS and GIS tools along with USLE.

\section{Materials and Methods}

\section{Study area}

Raigad is coastal district of Maharashtra state, situated in the western coast of India with geographical area is 7,152 sq.km and average annual rainfall is $3,884 \mathrm{~mm}$.

\section{Soil Erosion-USLE}

The Universal Soil Loss Equation (USLE) developed by Wischmeier and Smith, 1978 was used for estimation of soil loss. The equation given by,

$\mathrm{A}=\mathrm{R} \times \mathrm{K} \times \mathrm{L} \times \mathrm{S} \times \mathrm{C} \times \mathrm{P}$

Where, $\mathrm{A}$ is computed soil loss ( $\mathrm{t}$ ha/yr), $\mathrm{R}$ is the rainfall erosivity factor (MJ-mm/ha/hr/yr), $\mathrm{K}$ is the soil erodibility factor (t-ha$\mathrm{hr} / \mathrm{ha} / \mathrm{MJ} / \mathrm{mm}), \mathrm{L}$ is the slope length factor 
(m), S is the slope steepness factor, $\mathrm{C}$ is the crop cover-management factor, and $\mathrm{P}$ the conservation practice factor. The associated factors of the equation can be predicted by easily available meteorological and soil data.

\section{Rainfall erosivity factor $(\mathbf{R})$}

$\mathrm{R}$ is long term annual average of the product of event rainfall kinetic energy and the maximum intensity in 30 minutes in $\mathrm{mm}$ per hour. Rainfall erosivity estimation using rainfall data with long-time intervals have been attempted by several workers for different regions of the world. In the present study the daily rainfall data of Raigad district were collected from Department of Agriculture (period 1998-2016)but rainfall intensity data was not available. Erosivity index of Wakawali station of Dapoli was calculated by EI30 method (Nandgude et al., 2013). In this study, the relationship between daily EI30 values and daily precipitation was carried out by using regression equation developed for Ratnagiri district of Konkan region based on daily rainfall and EI30 data of Wakawali station (Salunkhe et al., 2018). The following equation implies the correlation between daily erosivity index and daily rainfall.

$Y=a X^{b}$

Where, $\mathrm{Y}$ is daily erosivity index and $\mathrm{x}$ is daily precipitation. The equation found was power in nature where $\mathrm{a}$ and $\mathrm{b}$ are constants (values of $a$ as 0.3339 and value of $b$ as 1.50). These values were assigned in ArcGIS 10.2 get rainfall erosivity $(\mathrm{R})$ map.

\section{Soil erodibility factor $(\mathbf{K})$}

The soil erodibility factor, $\mathrm{K}$, relates to the rate at which different soils erode due to inherent soil properties. The $\mathrm{K}$ factor was computed for each soil type of study area with the help of data obtained from soil analysis regarding soil texture, structure, permeability and organic matter content. An algebraic approximation of the nomograph that includes soil parameters such as texture, structure, permeability and organic matter content is proposed by the equation Wischmeier and Smith (1978) and Renard et al., (1997).,

$\mathrm{K}=\left\{\left[2.1 * 10^{-4} \mathrm{M}^{1.14}(12-\mathrm{a})+3.25(\mathrm{~b}-2)+2.5\right.\right.$ (c-3)] $/ 100\} * 0.1317$

Where, $\mathrm{K}=$ soil erodibility factor ( $\mathrm{t}$ ha $\mathrm{hr} / \mathrm{ha} / \mathrm{MJ} / \mathrm{mm}), \mathrm{b}=$ structure of the soil,

$\mathrm{M}=(\%$ silt $+0.7 * \%$ sand $) *(100-\%$ clay $)$, $\mathrm{c}=$ permeability of the soil, $\mathrm{a}=$ organic matter content ( $a=$ organic carbon $* 1.724)$.

In the present study the different soil parameters such as sand, silt, clay and organic carbon were collected from previous work Dr. B.S.K.K.V., Dapoli. Based on these data parameters required for erodibility estimation (equation 3) was determined by using various relationships among the soil characteristics. These $\mathrm{K}$ factor values were assigned to the different location of study area in ArcGIS 10.2 to get soil erodibility (K) map.

\section{Topographic factor (LS)}

Topographic factor (LS) in USLE accounts for the effect of topography on sheet and rill erosion. The two parameters that constitute the topographic factor are slope gradient (S) and slope length factor (L) and can be estimated from a digital elevation model (DEM). The relationship between the slope steepness in percentages (Sp) and slope length in meters (L) were used to generate slope length map. It is given by

$\mathrm{L}=0.4 * \mathrm{Sp}+40$

Where, $\mathrm{L}=$ Slope length in meters and $\mathrm{Sp}=$ 
Slope steepness in percentage. By applying this equation the resultant map was prepared for slope length.

Although $\mathrm{L}$ and $\mathrm{S}$ factors were determined separately, the procedure has been further simplified by combining the $\mathrm{L}$ and $\mathrm{S}$ factors together and considering the two as a single topographic factor (LS).Combined LS factor layer was generated as

I. For slopes up to $21 \%$, the equation modified $^{10}$ was used which is,

$\mathrm{LS} 1=(\mathrm{L} / 22.1) *\left(65.41 \sin ^{2} \theta+4.56 \sin \theta+\right.$ $0.065)$

Where, LS1 is the slope length and gradient factor and $\theta$ is angle of the slope.

II. For slope steepness of $21 \%$ or more, the equation used, which is given by

$\mathrm{LS} 2=(\mathrm{L} / 22.1)^{0.7} *\left(6.432 * \sin \left(\theta^{0.79}\right) * \cos \right.$ $(\theta))$

Where, LS2 is the slope length and gradient factor, $\theta$ is angle of the slope and $L$ is slope length in meters. Digital elevation model (DEM) of the study area was prepared using SRTM data. A slope map was created from the DEM, based on the slope map, slope length (L) and slope gradient(S) maps and finally a layer of LS factor was generated for Raigad district.

\section{Crop cover and management factor $(\mathrm{C})$}

The cover and management factor $(\mathrm{C})$ reflects the effect of cropping and management practices on soil erosion rates. LANDSAT8images were used for preparation of land use land cover map. Crop cover data of study area was collected from the District Superintending Agriculture Office, Raigad, Maharashtra to obtain the crop cover management factor $(\mathrm{C})$. The land use/cover classification of the study area was carried out using supervised classification (maximum likelihood classification). Classification was carried out for five land use classes: agriculture, forest, water body, barren land and settlement depend on the conservation measure applied to the study area. $\mathrm{P}$ factor was assigned as 1 for the study area as it was untreated.

\section{Estimation of tolerable soil loss}

The present model was provided to assess tolerable soil loss keeping in view its likely impact on crop yield and future availability of cultivable land. The soil erosion and productivity model was linked to crop productivity, which provides assessments for the estimation of tolerable soil loss. The loss of crop yield due to loss of top soil may be compensated by the formation of new soil through pedogenesis. It should be interested to observe that the process of soil formation and soil erosion occur simultaneously in nature. To calculate loss of topsoil it will be necessary to take into account the amount of soil regenerated and difference in the rate of soil formation under different types of climatic conditions. Therefore, the rate of topsoil formation will be considered as a factor in the model in assessing loss of productivity and tolerable soil losses. Topsoil formation at the rate of $1 \mathrm{~mm} / \mathrm{yr}$ was equivalent to an annual addition of $13.3 \mathrm{t} / \mathrm{ha}$, taking into account the weight of a hectare furrow slice (15 cm depth) soil as $2.2 \times 10^{6} \mathrm{~kg}$ Since, Raigad represents a tropical wet climate, the soil formation rate of $2.0 \mathrm{~mm}$ per year should be equivalent to an annual addition of $\left(2.2 \times 10^{6} / 150\right) \times 2.0=29 \mathrm{t} / \mathrm{ha}$ soil(Bhattacharya et al., 2007). On the basis of available data, soils have been classified in terms of their susceptibility to productivity loss of topsoil. These ranking of susceptibility of the soils were related to actual yield losses, 
and by input levels which were calculated by set of linear equations (Table 1).

On above table $\mathrm{x}=$ topsoil depth (in $\mathrm{cm}$ ). If $\mathrm{x}$ $=25 \mathrm{~cm}$, then in least susceptible soils with low input, yield loss was $25 \%$ as against 50 $\%$ and $175 \%$ in case of intermediate and most susceptible soils with low inputs. The tolerable loss rate for a given soil unit and specified amount and timescale of yield reduction was calculated by following equation,

$T L=\frac{\left(\left(\frac{R a}{R m} * 100 * B D * D\right)+3 T\right)}{T}$

Where, TL is tolerable soil loss rate ( $\mathrm{t} / \mathrm{ha} / \mathrm{yr}), \mathrm{Ra}$ is the acceptable yield reduction (\%), $\mathrm{Rm}$ is the yield reduction (\%) at the given input level when the effective top soil was lost, BD is bulk density of soil ( $\mathrm{Mg} / \mathrm{m}), \mathrm{D}$ is depth of effective topsoil $(\mathrm{cm})$ and $\mathrm{T}$ is time (years) over which reduction was acceptable.

To calculate the soil losses, soil-depth reduction may be measured in terms of proportion of the soils in an area that was shallower than a given depth due to erosion. The rate of soil loss is related to the proportion of land whose soil has become shallower than a specified depth by the following equation,

$P=\frac{S L * T}{B D * D}$

Where, $\mathrm{P}$ is proportion of land downgraded to at least the next depth class (\%), SL is soil loss (t/ha/yr), $\mathrm{T}$ is time (years), BD is bulk density of the soil $(\mathrm{Mg} / \mathrm{m})$ and $\mathrm{D}$ is depth range of soil class $(\mathrm{cm})$.The values of bulk density of different locations for all tehsils of Raigad district were adopted from M.Sc. theses (Joshi, 2013 and Sonawane, 2013).

\section{Results and Discussion}

\section{Rainfall erosivity factor $(R)$}

The average annual erosivity factor for Raigad district was found as 8387.47 MJ-mm /ha/hr/yr. These values were assigned in ArcGIS10.2 to get rainfall erosivity (R) map (Fig.1). Erosivity of Raigad district is very high due to very high intensity and high amount of rainfall.

\section{Soil erodibility factor (K)}

Soil erodibility factors were computed for 66 villages of Raigad district (using Eqn. 3). These $\mathrm{K}$ factor values were assigned to the different locations of study area in ArcGIS 10.2 to get soil erodibility (K) map (Fig.2). Soil erodibility factor for different locations of Raigad district was found in the range of 0.034 to0.083 t-ha-hr/ha/MJ/mm.

\section{Topographic factor (LS)}

The values of LS factors for Raigad were found in the range of 1.86 to 4.32. Major portion of Raigad district was covered by LS factor ranging between 1 and 2 (45.48 \%), followed by 2 to $3(21.10 \%)$ and 3 to 4 $(27.61 \%)$.

Very small portion of the study area was covered by LS factor more than $4(5.80 \%)$. LS factor map of Raigad district was generated in ArcGIS 10.2 (Fig. 3).

\section{Crop cover and management factor $(C)$}

LANDSAT-8 images used for preparation of land use/land cover map. Crop management factor values for Raigad district was ranging from 0.024 to 0.14 . C factor values for different land cover class were shown in Table 2, as per $\mathrm{C}$ factor map of Raigad district (Fig. 4). 


\section{Average annual soil loss using USLE}

The average annual soil loss for study area was calculated by annual average $\mathrm{R}$ (based on annual average rainfall data of 1998-2016), K, LS, $\mathrm{C}$ and $\mathrm{P}$ factors. All the layers viz. R, K, LS, $\mathrm{C}$ and $\mathrm{P}$ were generated in GIS and were overlaid to obtain the product, which gave average annual soil loss of the Raigad district. Classification of study area was done into six classes as slight, moderate, high, very high, severe, and very severe (Singh, 1992). Estimated average annual soil loss from Raigad district was 38.22t/ha/yr (Fig. 5). It was observed that about $2.31 \%$ area was under slight erosion class, $22.9 \%$ area was under moderate erosion class, $12.40 \%$ area was under moderately severe erosion class, $27.6 \%$ area was under severe erosion class, $20.99 \%$ area was under very severe erosion class and $13.8 \%$ area was under extremely severe erosion class of Raigad district before soil and water conservation measures. It showed that more than $80 \%$ of area comes under severe to extremely severe erosion class which was major cause of concern. This proves an urgent need of soil and water conservation measures in the watershed for the sustainable management of natural resources.

\section{Tolerable soil loss}

Estimation of tolerable soil loss has been done (i) through value of yield loss that can be tolerated or (ii) the proportion of land (\%) that can be allowed to make the depth of soil shallower at least by one soil depth class over a specified time period. It has been found that these two ways to estimate the soil loss do not produce same values. The tolerable soil losses for all tehsils of Raigad district were estimated over a specified time period of 100 years. The tolerable soil loss calculated through the second method (Eqn. 8) often produces a lower estimate than first method (Eqn. 7) which was shown in Table 3.

\section{Total annual soil loss in Raigad district}

In Raigad, total six classes of soil erosion were identified. Taking the median values of the soil erosion range, the total soil loss under different erosion classes was estimated (Table $5)$. There is an estimated annual addition of $29 \mathrm{t} /$ ha soil in Raigad district. The annual loss of soil has been estimated as nearly about 24.06 million tonnes every year.

Table.1 Relationship between topsoil loss and yield loss

\begin{tabular}{|l|l|c|}
\hline Soil susceptibility & Input level & Yield loss $(\mathbf{y}, \mathbf{\%})$ \\
\hline \multirow{2}{*}{ Least susceptible } & Low & $\mathrm{y}=1.0 \mathrm{x}$ \\
\cline { 2 - 3 } & Intermediate & $\mathrm{y}=0.6 \mathrm{x}$ \\
\cline { 2 - 3 } Intermediate susceptible & High & $\mathrm{y}=0.2 \mathrm{x}$ \\
\cline { 2 - 3 } & Low & $\mathrm{y}=2.0 \mathrm{x}$ \\
\cline { 2 - 3 } & Intermediate & $\mathrm{y}=1.2 \mathrm{x}$ \\
\cline { 2 - 3 } & High & $\mathrm{y}=0.4 \mathrm{x}$ \\
\hline \multirow{2}{*}{ Most susceptible } & Low & $\mathrm{y}=7.0 \mathrm{x}$ \\
\cline { 2 - 3 } & Intermediate & $\mathrm{y}=5.0 \mathrm{x}$ \\
\hline & High & $\mathrm{y}=3.0 \mathrm{x}$ \\
\hline
\end{tabular}

(Source: Bhattacharya et al., 2007). 
Table.2 Land use/land cover and C value

\begin{tabular}{|l|c|}
\hline \multicolumn{1}{|c|}{ Land use/land cover } & C value \\
\hline Forest(Rasool et al., 2014) & 0.04 \\
\hline Barren land (Rasool et al., 2014) & 0.034 \\
\hline Built-up (Rasool et al., 2014) & 0.024 \\
\hline Horticultural crops (Pal and Samanta, 2011) & 0.1 \\
\hline Oilseeds (Panagos et al., 2015) & 0.28 \\
\hline Rice (Panagos et al., 2015) & $\mathbf{0 . 1 5}$ \\
\hline
\end{tabular}

Table.3 Proportion of land downgraded from given classes due to soil loss in Raigad district (over a 100 year period)

\begin{tabular}{|c|c|c|c|c|c|c|}
\hline \multicolumn{7}{|c|}{ Raigad } \\
\hline \multirow[t]{2}{*}{ Soil depth class and change (cm) } & \multicolumn{6}{|c|}{$\begin{array}{l}\text { Amount of land lost (\% of class) at erosion } \\
\text { rates }(\mathrm{t} / \mathrm{ha} / \mathrm{hr})\end{array}$} \\
\hline & 5 & 10 & 25 & 50 & 75 & 100 \\
\hline From shallow $(<25 \mathrm{~cm})$ to bedrock $(0)$ & 15.81 & 31.62 & 79.06 & 100 & & \\
\hline $\begin{array}{l}\text { From moderately shallow }(25-50 \mathrm{~cm}) \text { to } \\
\text { shallow }(<25 \mathrm{~cm})\end{array}$ & 15.81 & 31.62 & 79.06 & 100 & & \\
\hline $\begin{array}{l}\text { From moderately deep }(50-100 \mathrm{~cm}) \text { to } \\
\text { moderately shallow }(25-50 \mathrm{~cm})\end{array}$ & 5.26 & 10.68 & 22.35 & 52.70 & 79.06 & 98.39 \\
\hline $\begin{array}{l}\text { From deep }(100-150 \mathrm{~cm}) \text { to moderately } \\
\text { deep }(50-100 \mathrm{~cm})\end{array}$ & 3.156 & 6.37 & 15.81 & 31.62 & 47.43 & 61.25 \\
\hline $\begin{array}{l}\text { From very deep }(>150 \mathrm{~cm}) \text { to deep }(100-150 \\
\mathrm{cm})\end{array}$ & 2.63 & 5.26 & 13.17 & 26.35 & 39.53 & 52.70 \\
\hline
\end{tabular}

Table.4 Tolerable soil loss (t/ha/yr) equivalent to $10 \% \mathrm{P}$ of the proportion of land downgraded and $>50 \%$ reduction in crop yield at low input level over 100 years (calculation assumes a minimum of $25 \mathrm{~cm}$ depth for crop production)

\begin{tabular}{|l|c|c|c|c|c|c|}
\hline \multicolumn{1}{|c|}{ Roigad susceptibility } & \multicolumn{2}{|c|}{ Low Rm= 25\% } & \multicolumn{2}{c|}{$\begin{array}{c}\text { Intermediate } \mathbf{R m}= \\
\mathbf{5 0 \%}\end{array}$} & \multicolumn{2}{c|}{ High $\mathbf{R m = 1 7 5 \%}$} \\
\hline Shallow (<25) & 0 & 0 & 0 & 0 & 0 & 0 \\
\hline $\begin{array}{l}\text { Moderately shallow } \\
\text { (25-50) }\end{array}$ & 3.17 & 66.6 & 3.17 & 34.8 & 3.15 & 12.08 \\
\hline $\begin{array}{l}\text { Moderately deep (50- } \\
\text { 100) }\end{array}$ & 9.53 & 66.6 & 9.53 & 34.8 & 9.53 & 12.08 \\
\hline Deep (100-150) & 15.89 & 66.6 & 15.89 & 34.8 & 15.89 & 12.08 \\
\hline Very deep (>150) & 19.08 & 66.6 & 19.08 & 34.8 & 19.08 & 12.08 \\
\hline
\end{tabular}


Table.5 Total annual soil loss in Raigad

\begin{tabular}{|c|c|c|c|}
\hline Soil erosion class & $\begin{array}{c}\text { Range } \\
\text { (t/ha/yr) }\end{array}$ & Area (ha) & $\begin{array}{c}\text { Soil loss } \\
\text { (million tons)/yr }\end{array}$ \\
\hline Slight & $0-5$ & 16084.53 & 0.04021 \\
\hline Moderate & $5-10$ & 158433.43 & 1.18825 \\
\hline Moderately severe & $10-20$ & 85764.412 & 1.2864 \\
\hline Severe & $20-40$ & 192102.57 & 5.7630 \\
\hline Very severe & $40-80$ & 145604.70 & 8.73628 \\
\hline Extremely severe & $>80$ & 95679.220 & 9.5679 \\
\hline Total & - & 693653.87 & $\mathbf{2 6 . 5 8}$ \\
\hline Effective soil loss & - & & $\mathbf{2 4 . 0 6}$ \\
\hline
\end{tabular}

Table.6 Soil loss values over 7 years (for moderately deep soils) criteria given by Singh etal., (1992)

\begin{tabular}{|c|l|c|c|}
\hline \multirow{2}{*}{ Year } & \multicolumn{1}{|c|}{ Land use } & \multicolumn{2}{|c|}{ Soil loss (t/ha) } \\
\cline { 3 - 4 } & & Annual & Total \\
\hline $\mathbf{1}$ & Crop- $^{\text {st }}$ year & 12 & 12 \\
\hline $\mathbf{2}$ & Crop-2 $^{\text {nd }}$ year & 18 & 18 \\
\hline $\mathbf{3}$ & Crop- $^{\text {rd }}$ year & 25 & 25 \\
\hline $\mathbf{4}$ & Fallow & 4 & 4 \\
\hline $\mathbf{5}$ & Crop-1 $^{\text {st }}$ year & 12 & 12 \\
\hline $\mathbf{6}$ & Crop-2 $^{\text {nd }}$ year & 18 & 18 \\
\hline $\mathbf{7}$ & Fallow & 4 & 4 \\
\hline Total soil loss over 7 years & & & 93 \\
\hline
\end{tabular}

Table 7.Area under different classes of soil erosion after conservation measures of Raigad District

\begin{tabular}{|l|c|c|c|}
\hline Soil erosion class & Soil loss (t/ha/yr) & Area (ha) & \% area \\
\hline Slight & $0-5$ & 450616.81 & 64.78 \\
\hline Moderate & $5-10$ & 75701.15 & 10.88 \\
\hline Moderately severe & $10-20$ & 75701.15 & 10.88 \\
\hline Severe & $20-40$ & 55122.85 & 7.92 \\
\hline Very severe & $40-80$ & 38499.05 & 5.53 \\
\hline
\end{tabular}


Fig.1 Rainfall Erosivity map of Raigad district

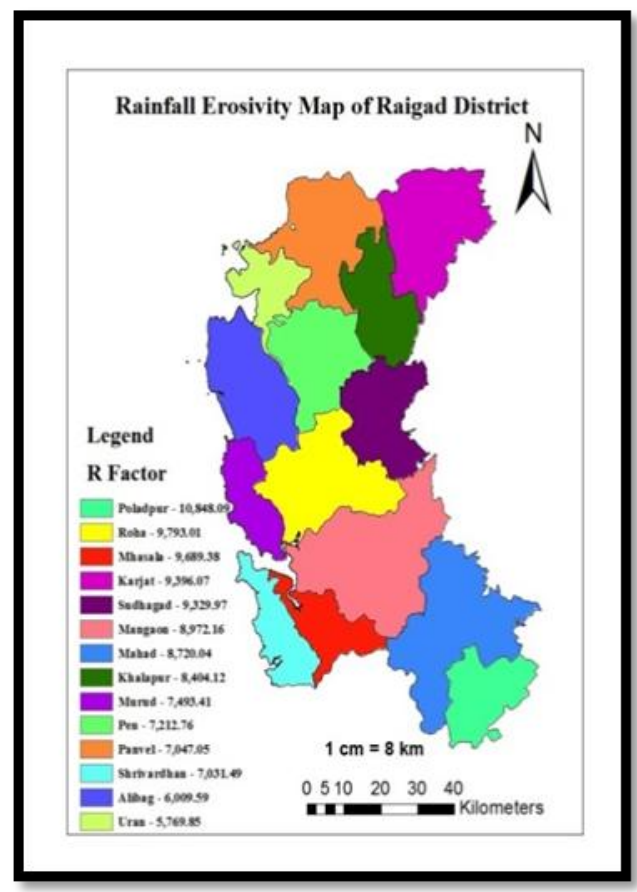

Fig.3 Topographic factor map of Raigad district

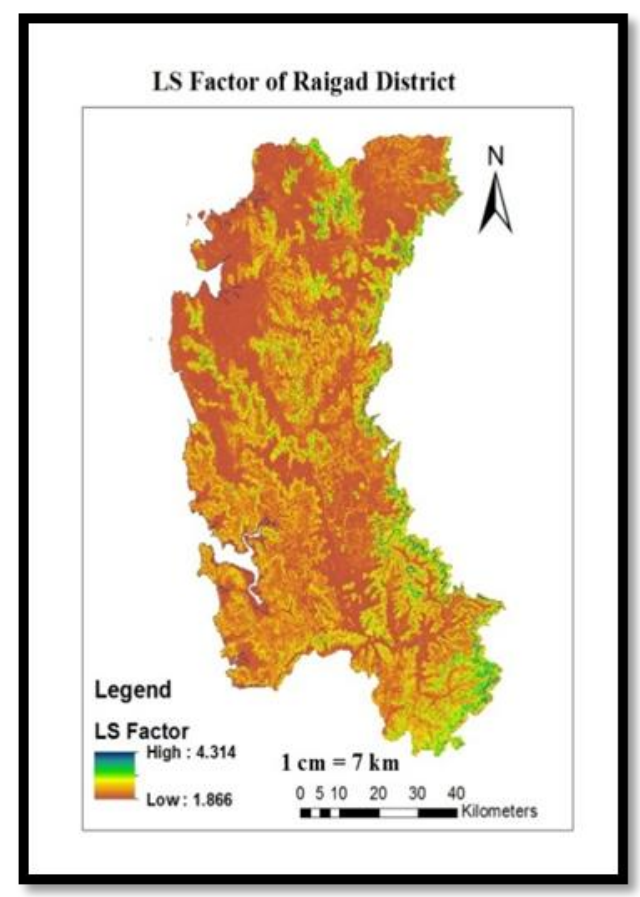

Fig 2 Soil erodibility map of Raigad district

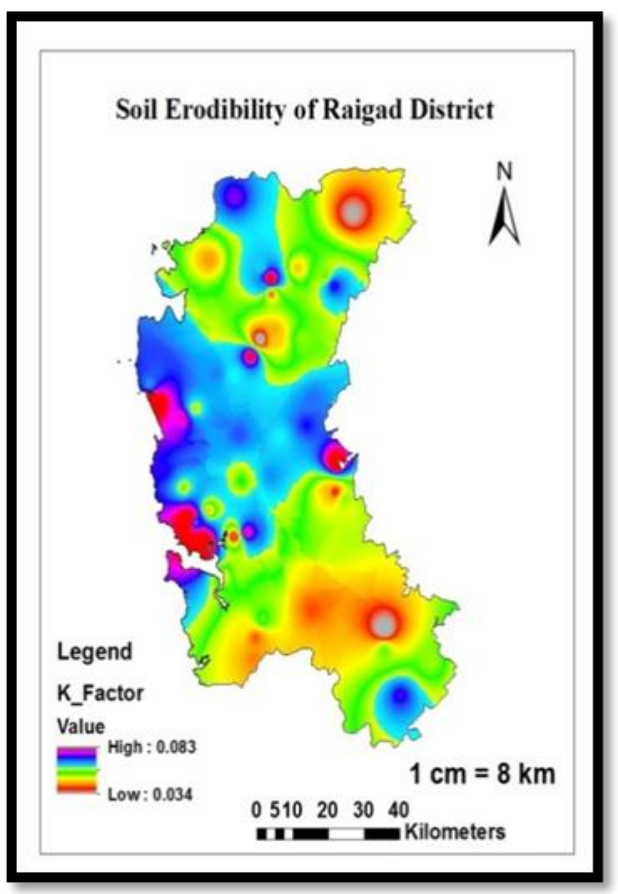

Fig.4 Crop cover management map of Raigad district

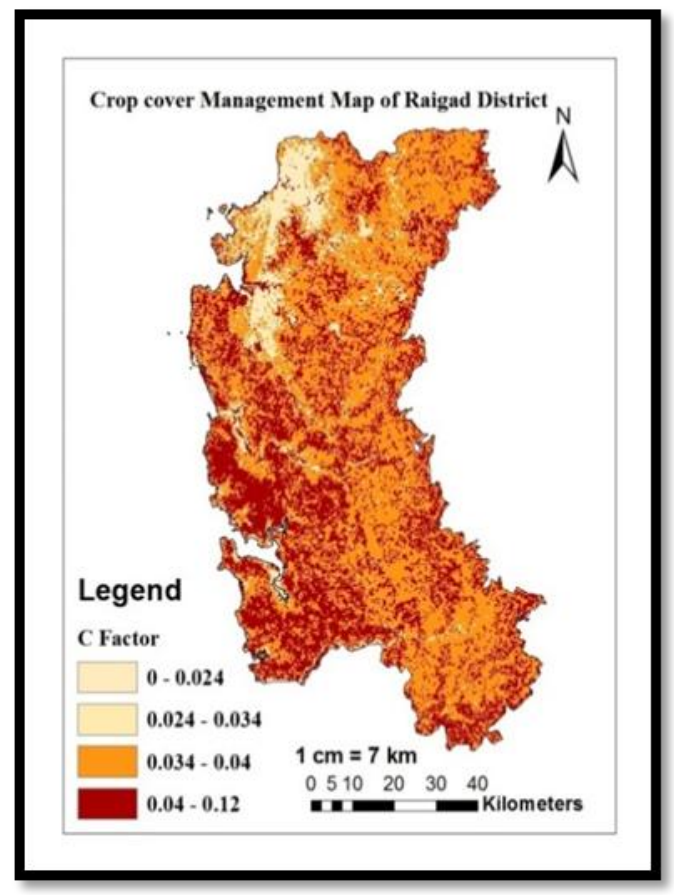


Fig.5 Average annual soil loss map of Raigad district before conservation measures

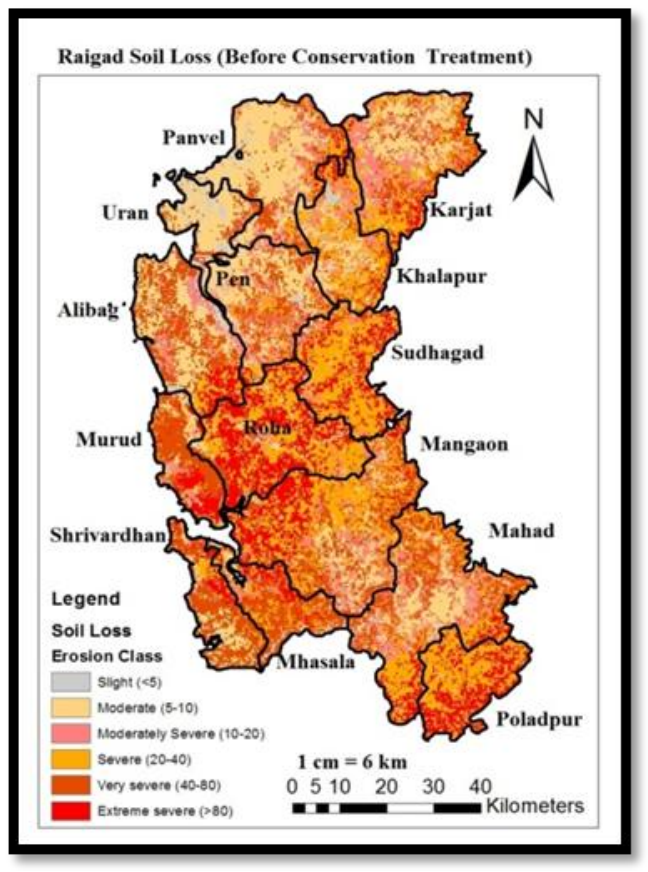

\section{Estimation of conservation need $(P)$ factor}

The soil conservation need was estimated as the protection factor $(\mathrm{P})$ when lands are not under any conservation programmes. The average rate of erosion covers both the cultivated and uncultivated parts of the crop and fallow period cycle. For Raigad district, different crop and fallow cycles of 4 yrs to 10 yrs periods were tested to reduce soil loss below tolerable limit and get maximum crop years. Hence, by using accurate crop and fallow period cycle, the conservation practice factor were obtained for all tehsils of Raigad district.

Thus, out of 4 years to 10 years crop cycles tested, 7 years crop cycle (Table 6) gave maximum crop year and minimum conservation practice factor to keep soil loss in tolerable limit. The total soil loss over 7 years crop cycle was 93 t/ha. The soil loss reduction were estimated for Raigad and
Fig.6 Average annual soil loss map of Raigad district after conservation measures

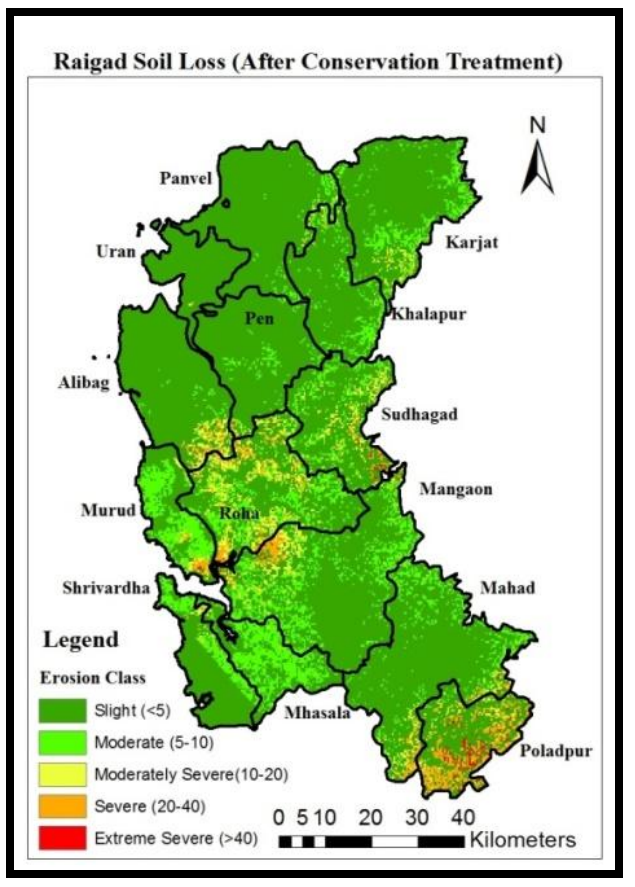

district, e.g. required soil loss reduction for Khalapur tehsil of Raigad district was 32.66 t/ha (93-60.34 t/ha). The total soil loss over 5 years was $85 \mathrm{t} / \mathrm{ha} / \mathrm{yr}(12+18+25+12+18 \mathrm{t} / \mathrm{ha})$ excluding fallow years from seven year crop cycle. Therefore, the estimated conservation practice factor $(\mathrm{P})$ was $0.38(32.66 / 85)$ for Khalapur tehsil of Raigad district. Thus, conservation practice factor (P) were calculated for study area was in the range of $0.20-0.38$ for Raigad District. The estimated average $\mathrm{P}$ factor for Raigad district was 0.32 district.

\section{Estimation of average annual soil loss after conservation measures}

Annual soil loss was calculated for study area after recommendation of soil and water conservation measures. Annual soil loss for Raigad after soil and water conservation measures was calculated as $9.18 \mathrm{t} / \mathrm{ha} / \mathrm{yr}$ (Fig. 7). Soil Classification of micro watershed was 
done into six classes as slight, moderate, high, very high, severe, and very severe as per criteria given by Singh et al., (1992).

Due to recommendation of soil and water conservation measures soil loss 9.18 (t/ha/yr) was expected to reduce from the Raigad District. About $10.88 \%$ area was expected to come under moderate erosion class, $64.78 \%$ area was under slight erosion class, $7.92 \%$ area under severe erosion class, $10.88 \%$ area was under moderately severe erosion class, and $5.53 \%$ area under very severe erosion class.

In conclusion, estimated average annual soil loss from Raigad district using USLE was found as $38.22 \mathrm{t} / \mathrm{ha} / \mathrm{yrbefore}$ adopting the soil and water conservation measures. About more than $80 \%$ of area comes under severe to extremely severe erosion class of Raigad district before adopting the soil and water conservation measures.Estimated average tolerable soil loss for district was $9.53 \mathrm{t} / \mathrm{ha} / \mathrm{yr}$ for moderately deep soil. The estimated average conservation practice factors $(\mathrm{P})$ were 0.32 for Raigad district. Thus, estimated soil loss from Raigad district using USLE were $9.18 \mathrm{t} / \mathrm{ha} / \mathrm{yrafter}$ adoption of soil and water conservation measures. However, by adopting soil and water conservation measures $80 \%$ area will be expected to come under slight erosion class to moderate erosion class of Raigad district.

\section{References}

Belasri, A., and Lakhouili A.(2016). Estimation of Soil Erosion Risk Using the Universal Soil Loss Equation (USLE) and Geo-Information Technology in Oued El Makhazine Watershed, Morocco. Journal of Geographic Information System. 8: 98107.

Bhattacharyya, T., R. Babu, D. Sarkar, C.
Mandal, B. L. Dhyani and A. P. Nagar. 2007. Soil loss and crop productivity model in humid subtropical India. Current Science, Vol. 93 (10): 1397 1403.

Durbude, D., 2015. Hydrological impact assessment of SWC measures in Ralegaon Siddhi model watershed. Indian Journal of Soil Conservation.43(3): 197-203.

Kassam, A. H., V. Velthuizen, G. W. Fischer and ShalM. M. 1991. Agro-ecological land resource assessment for agricultural development and planning. A case study of Kenya resources database and land productivity. Land and Water Development and Division, Food and Agriculture Organization of the United Nations and International Institute of Applies Systems Analysis, Rome.

Kothari, U., 1996. Erosion and sedimentation problem in India.International Association of Hydroloical Sciences. 236.

Montgomery, D., 2007. Soil erosion and agricultural sustainability. PNAS, 104: 13268-72.

Myers, N., R. A. Mittermeier, C. G. Mittermeier, G. A. B. Da Fonseca and Kent J. 2000. Biodiversity hotspots for conservation priorities. Nature. 403:853-858.

Nandgude, S., V. Shinde, D. Mahale and Singh M. 2013. Synthesis of Rainfall Characteristics for Predicting the Erosivity Pattern of Wakavali Region in Maharashtra, India.Journal of Hydrologic Engineering. 18:92-98.

Narayana, D., and Babu. R. 1983. Estimation of soil erosion in India.Journal of Irrigation Drainage Engineering. 109: 419-434.

Pal, B., and Samanta, S. 2011. Estimation of soil loss using RS and GIS techniques (Case study of Kaliaghai River basin, 
Purba \& PaschimMedinipur District, West Bengal, India). Indian Journal of Science and Technology.4(10): 12021207.

Panagos, P., 2015. Estimating the soil erosion cover-management factor at the European scale. Land Use Policy. 48:38-50.

Parveen, R., and Kumar, U. 2012. Integrated Approach of Universal Soil Loss Equation (USLE) and Geographical Information System (GIS) for Soil Loss Risk Assessment in Upper South Koel Basin, Jharkhand. Journal of Geographic Information System. 4: 588-596.

Rasool, S. N., S. W. Gaikwad and SaptarshiP. G. 2014. Soil Erosion Assessment In Sallar Wullarhama Watershed In The Lidder Catchment Of Jammu And Kashmir Using, Usle, GIS and RS. International Journal of Advanced Engineering Research and Studies.4654.

Renard, K. G., G. A. Foster, D. K. McCool Weesies and Yoder D. C. 1997.
Prediction of soil erosion by water: a guide to conservation planning with the revised universal soil loss equation (RUSLE), Agricultural Handbook 703, USDA, Washington, DC.

Salunkhe, S., 2018. Estimation of soil erosion and nutrient loss by USLE model for Ratnagiri district. Advanced Agricultural Research and Technology Journal. 2(1): 53-61.

Singh, G., R. Babu, P. Narain, L. S. Bhusanand AbrolI. P. 1992. Soil erosion rates in India. Journal of Soil and Water Conservation.47(1): 97-99.

Thawakar, S., 2014. Estimation of Erodibility at Selected Locations in Konkan Region. Published M. Tech. Thesis submitted to Department of Soil and Water Conservation Engineering, Dr. B. S. K. K. V. Dapoli.

Wischmeier, W., and Smith, D. 1978. Predicting rainfall erosion losses- A guide to conservation planning. Agricultural Handbook No. 537, USDA.

\section{How to cite this article:}

Madhuri Phadtare, Sachin Nandgude, Sanjani Salunkhe and Dilip Mahale. 2020. Soil Erosion and Crop Productivity Loss for Raigad District of Konkan Region. Int.J.Curr.Microbiol.App.Sci. 9(02): 1655-1666. doi: https://doi.org/10.20546/ijcmas.2020.902.191 